\title{
Strategi Belajar Bahasa Inggris pada Era Revolusi Digital 4.0 di Komunitas Duta Bahasa Provinsi Bangka Belitung
}

\author{
Eka Dyah Puspita Sari ${ }^{1 *}$, Ummi Nurjamil Baiti Lapiana $^{2}$, Memet Sudaryanto ${ }^{3}$ \\ ${ }_{1,2,3}$ Fakultas Ilmu Budaya, Universitas Jenderal Soedirman, Indonesia \\ Email: ${ }^{1}$ eka.dyah@unsoed.ac.id, ${ }^{2}$ ummi.nurjamil@ unsoed.ac.id, ${ }^{3}$ memet.sudaryanto@unsoed.ac.id
}

\section{INFORMASI ARTIKEL}

\section{Data artikel:}

Naskah masuk, 28 Agustus 2021

Direvisi, 16 Oktober 2021

Diiterima, 19 November 2021

\section{Kata Kunci:}

English

Learning Strategy

Digital Revolution 4.0

\section{Korespondensi:}

\begin{abstract}
ABSTRAK
Abstract- Language is one of the crucial components to face industrial revolution 4.0. Mastery in English, as a foreign language, can be beneficial for people. It can give us chance to explain information, to tell the fact, and to express ideas in various communities in the world. Some ways can be implemented in autonomous learning in digital era 4.0. They are extensive reading and improving writing skills. Extensive reading is an approach to learning English by implementing much time to read books in a short time. The second way is improving writing skills. The role of improving writing skills is to boost academic and career achievements. When someone improves his academic and career, he automatically improves his self-esteem in communicating and interacting with others in English.
\end{abstract}

\begin{abstract}
Abstrak- Bahasa menjadi salah satu komponen penting untuk menghadapi revolusi industri 4.0. Penguasaan bahasa Inggris sebagai bahasa asing dapat memberikan keuntungan untuk menjelaskan informasi, menyampaikan fakta, dan mengutarakan ide serta gagasan dengan berbagai komunitas di dunia. Beberapa cara dapat diambil untuk belajar Bahasa Inggris sendiri dalam era digital $4.0 \mathrm{ini}$, seperti membaca ekstensif dan mengembangkan kemampuan menulis. Membaca ekstensif merupakan pendekatan pembelajaran Bahasa Inggris dengan cara membaca banyak bacaan dalam waktu yang cepat. Cara yang kedua adalah dengan mengembangkan kemampuan menulis. Peran dari mengembangkan kemampuan menulis adalah mempercepat peningkatan dalam akademik dan karir. Saat seseorang sudah mengalami peningkatan dalam akademik dan karir, secara otomatis orang tersebut juga meningkatkan kepercayaan dirinya dalam berkomunikasi dan berinteraksi dengan orang lain dalam Bahasa Inggris.
\end{abstract}

\section{Eka Dyah Puspita Sari}

Fakultas Ilmu Budaya, Universitas Jenderal Soedirman

Jl. DR. Soeparno No.60, Karangwangkal, Kec. Purwokerto Utara, Kabupaten Banyumas, Jawa Tengah 53122 


\section{PENDAHULUAN}

Revolusi industri menjadi pembahasan yang menarik saat ini, karena Indonesia semakin konsen untuk menyiapkan diri memasuki era industri 4.0 yang serba canggih. Dalam pembelajaran di era digital 4.0 ini, seseorang tidak dapat hanya bergantung pada bantuan guru dan sekolah dalam belajar. Bantuan dari komunitas yang berfokus pada bahasa juga dapat menjadi salah satu cara untuk memaksimalkan proses belajar (Purwati \& Perdanawanti, 2019). Komunitas Duta Bahasa Provinsi Bangka Belitung merupakan salah satu komunitas yang berisi para agen muda yang merupakan perpanjangan tangan dari Badan Bahasa Kementerian Pendidikan dan Kebudayaan. Komunitas ini secara aktif mengadakan berbagai kegiatan untuk mendukung penggunaan bahasa dalam berbagai perubahan era yang terjadi.

Bahasa menjadi salah satu komponen penting untuk menunjang hal tersebut. Bahasa juga menjadi salah satu elemen penting dari kemajuan bangsa. Di Indonesia, penilaian keterampilan berbahasa sebagian besar masih diukur melalui penguasaan konsep bahasa, bukan lagi keterampilan menerapkan faktor dimensional dalam bahasa sebagai modal utama komunikasi. Tren di Indonesia sekarang juga menggiring pada tingkat penguasaan bahasa asing.

Penguasaan bahasa asing pada saat ini menjadi prioritas penting sebagai salah satu tuntutan zaman, selain penguasaan teknologi yang mumpuni. Menguasai bahasa asing dapat memberikan keuntungan untuk memahami budaya dari negara lain. Tingkat penguasaan bahasa asing di Indonesia seyogyanya tidak hanya diukur dari tingkat penguasaan konsep saja, tetapi lebih kepada kemampuan menjelaskan informasi, menyampaikan fakta, dan mengutarakan ide serta gagasan. Hal ini akan memudahkan seseorang untuk terhubung dengan orang dari latar belakang budaya dan bahasa yang berbeda, serta akan memberikan kesempatan yang lebih untuk bersaing dalam era revolusi industri 4.0 ini.

Dalam menghadapi era revolusi industri 4.0 ini, Komunitas Duta Bahasa Provinsi Bangka Belitung juga bersiap menghadapinya dengan mengadakan berbagai kegiatan yang dapat memberikan manfaat bagi masyarakat. Salah satu kegiatan yang dapat dilakukan adalah dengan mengadakan seminar untuk membantu mempersiapkan masyarakat menghadapi era revolusi industri 4.0. Kegiatan seminar ini mengangkat tema "Peran Bahasa dan Sastra pada Era Revolusi Industri 4.0" yang kemudian berfokus pada topik "Strategi Belajar Bahasa Inggris pada Era Digital 4.0".

Hal ini sejalan dengan beberapa kegiatan pengabdian lainnya yang menitik beratkan pada penguasaan bahasa Inggris. Kegiatan pengabdian tentang pengenalan bahasa Inggris bagi anak usia dini juga sudah pernah diadakan sebelumnya (Muliyah \& Fernando, 2019). Dalam kegiatan ini, deskripsi pembelajaran pengenalan bahasa Inggris menjadi fokus utama. Hasil kegiatan menunjukkan bahwa faktor penghambat dalam pembelajaran pengenalan bahasa Inggris pada anak usia dini yaitu bahasa Inggris bukan merupakan bahasa utama yang digunakan anak-anak, sehingga guru harus kreatif dalam mengajar dengan kondisi guru kelas tidak memiliki pengetahuan Bahasa Inggris yang cukup memadai. Hal ini menunjukkan bahwa tingkat kompetensi keahlian guru dalam mengajar bahasa Inggris belum tersebar secara merata, sehingga diperlukan cara lain agar guru-guru dapat mengembangkan kompetensi bahasa Inggris mereka dan siap menghadapi era 4.0 yang banyak menggunakan bahasa Inggris. Selain itu, kegiatan pengabdian yang berfokus pada peningkatan kemampuan mahasiswa juga sudah dilakukan (Permata \& Hadiani, 2018). Pengabdian ini didasarkan pada tingkat pengajaran bahasa Inggris yang belum merata di seluruh daerah di Indonesia sehingga menyebabkan daya saing mahasiswa menjadi rendah. Hasil kegiatan ini menunjukkan bahwa 
kemampuan bahasa Inggris mahasiswa meningkat, tetapi tetap dibutuhkan ketekunan dari mahasiswa untuk belajar lebih baik lagi agar keterampilannya dapat meningkat secara signifikan. Hal ini juga menunjukkan bahwa tingkat penguasaan kompetensi bahasa Inggris menjadi salah satu daya saing yang berperan penting dalam semua hal, termasuk dalam menghadapi era revolusi industri 4.0. Kegiatan pengabdian lainnya yang berfokus pada pentingnya kemampuan bahasa Inggris juga telah dilakukan (Firmansyah et al., 2021). Dalam kegiatan ini, metode pelaksanaan yang dipilih yaitu melalui pelatihan peningkatan kemampuan berbicara bahasa Inggris, melalui latihan-latihan seperti diskusi, storytelling, wawancara dan lain-lain. Kegiatan pengabdian lain yang berfokus pada pentingnya kemampuan bahasa Inggris juga telah dilakukan (Tamrin \& Yanti, 2019). Hasil kegiatan pengabdian masyarakat menunjukkan bahwa penguasaan bahasa Inggris penting untuk dikuasai dan pembelajaran Bahasa Inggris berbasis buku cerita bertema alam lebih mudah di mengerti oleh siswa yang diajar.

Kegiatan pengabdian lain yang berfokus pada kemampuan bahasa Inggris juga sudah dilakukan dengan judul "Manfaat Pembelajaran Bahasa Inggris Berbasis Folklor untuk Pengembangan Pariwisata" (Noviana et al., 2018). Kegiatan lainnya yang juga berfokus pada kemampuan bahasa Inggris adalah "Sosialisasi Pentingnya Menguasai Bahasa Inggris Bagi Mahasiswa" (Thariq et al., 2021). Kegiatan ini bertujuan agar mahasiswa dapat lebih terpacu dan termotivasi untuk lebih mengasah penguasan bahasa Inggris yang dimilikinya, agar memiliki wawasan yang bersifat internasional dan berguna sebagai alat untuk menjawab tantangan perkembangan ilmu pengetahuan di era globalisasi.

Selain itu, kegiatan pengabdian untuk menyongsong Revolusi Industri 4.0 juga telah dilakukan. Literasi Digital di Era Revolusi
Industri 4.0 merupakan salah satu kegiatan pengabdian untuk mempersiapkan era Revolusi Industri 4.0 (Lestari \& Erwanto, 2021).

Dari beberapa kegiatan pengabdian terdahulu, dapat disimpulkan bahwa tingkat penguasaan kompetensi bahasa Inggris sangat penting, mulai dari anak usia dini hingga mahasiswa, terutama untuk menghadapi era digital 4.0. Tingkat pengajaran dan pembelajaran bahasa Inggris di Indonesia selama ini belum merata dan masih mengandalkan pada kemampuan guru saja.

Adapun target dari kegiatan ini adalah untuk menumbuhkan minat dan motivasi belajar bahasa Inggris dengan strategi belajar yang dapat membantu menghadapi era digital 4.0. Luaran dari kegiatan ini adalah tumbuhnya semangat, minat, dan motivasi belajar bahasa Inggris para peserta.

\section{METODE PELAKSANAAN}

Kegiatan pengabdian kepada masyarakat ini dilaksanakan secara daring di Komunitas Duta Bahasa Provinsi Bangka Belitung yang bekerja sama dengan Kantor Bahasa Provinsi Bangka Belitung, Penerbit Dapur Kata dan Komunitas Kebun Kata. Kegiatan seminar daring ini dilaksanakan pada tanggal 30 April 2021 dengan jumlah peserta seminar yang ikut serta dalam kegiatan ini sebanyak 60 orang. Peserta seminar daring ini terdiri dari berbagai latar belakang yang berbeda. Beberapa perserta merupakan guru mata pelajaran bahasa Inggris dan mata pelajaran lainnya, dan sebagian peserta merupakan pelajar atau mahasiswa yang tertarik dengan strategi pembelajaran bahasa Inggris untuk menghadapi era revolusi digital 4.0. Tingginya minat peserta seminar yang mengikuti kegiatan ini menunjukkan bahwa masyarakat sangat bersiap untuk menghadapi era revolusi industri 4.0 dengan belajar bahasa Inggris sebagai salah satu bekal.

Metode pelaksanaan kegiatan ini digambarkan dalam bentuk diagram 1 . 


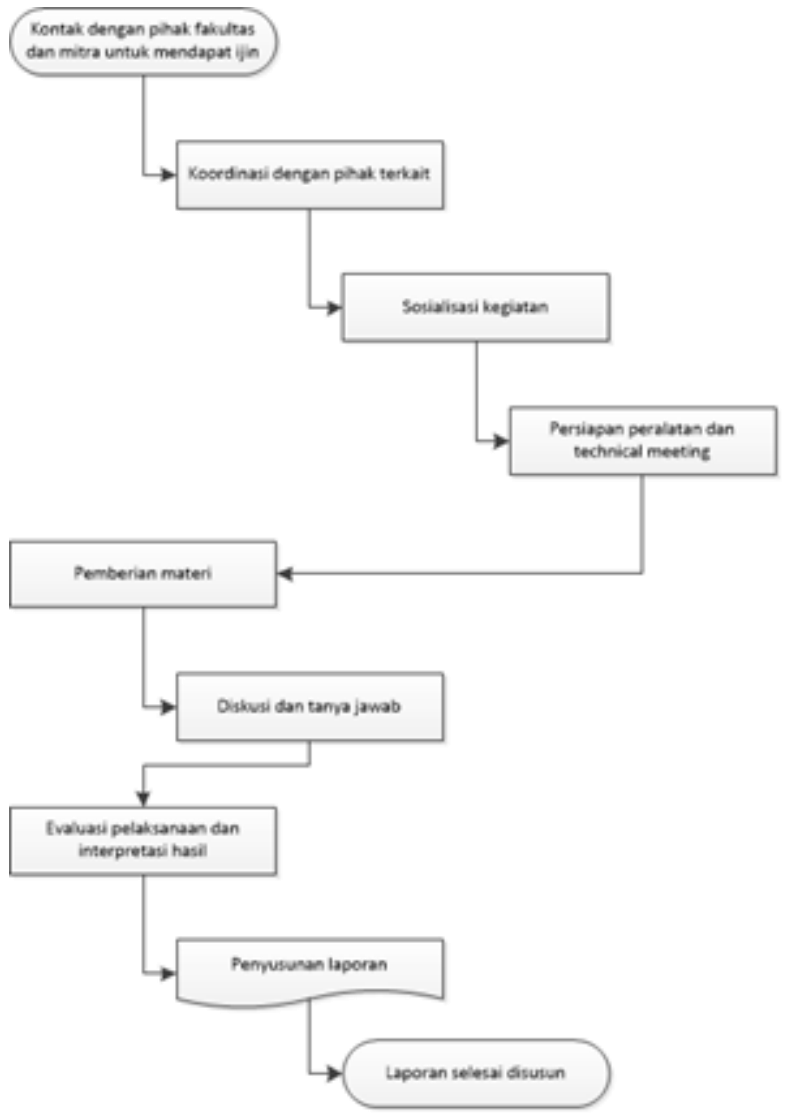

Gambar 1. Metode pelaksanaan kegiatan

Metode pelaksanaan kegiatan pengabdian ini dapat dijabarkan sebagai berikut:

1. Tahap persiapan (Planning)

a. Tim kerja melakukan kontak dengan pihak Fakultas Ilmu Budaya, Universitas Jenderal Soedirman dan mitra, yaitu Komunitas Duta Bahasa Provinsi Bangka Belitung, Penerbit Dapur Kata, dan Komunitas Kebun Kata.

b. Tim kerja melakukan koordinasi dengan pihak terkait untuk menentukan tanggal dan waktu pelaksanaan kegiatan.

c. Tim kerja dan mitra melakukan sosialisasi kegiatan seminar kepada masyarakat umum, khususnya di Provinsi Bangka Belitung. Kegiatan sosialisasi ini dilakukan dengan cara menyebarkan poster yang sudah dibuat.

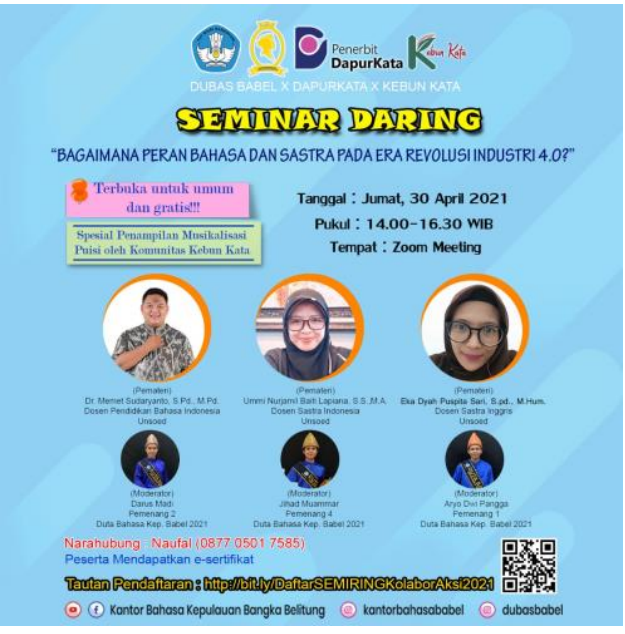

Gambar 2. Poster Kegiatan Seminar

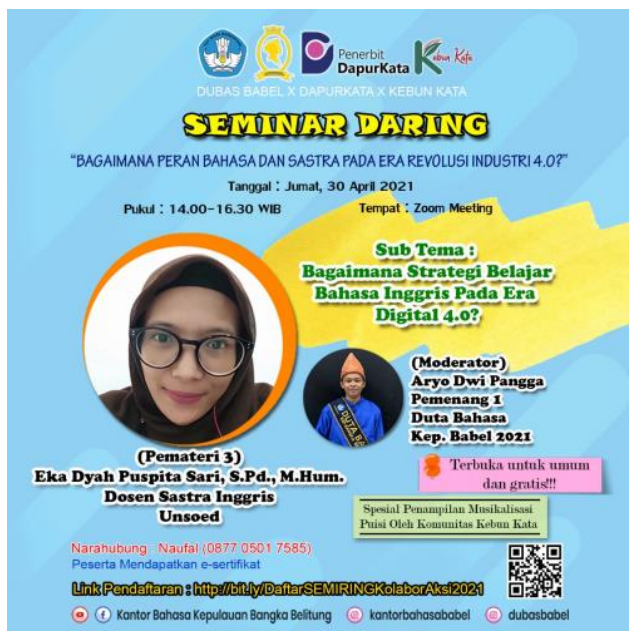

Gambar 3. Poster Strategi Belajar Bahasa Inggris

d. Tim kerja dan mitra melakukan persiapan peralatan yang dibutuhkan. Technical meeting atau teknik pelaksanaan kegiatan juga dilaksanakan pada tahap ini.

2. Tahap pelaksanaan (Implementing)

Kegiatan seminar daring ini dilaksanakan dengan lancar sesuai dengan jadwal dan agenda yang sudah disusun sebelumnya. dan Materi atau paparan dari tim kerja dan partisipasi aktif dari peserta seminar dalam sesi tanya jawab membuat situasi dan kondisi seminar daring ini berjalan secara menarik. Suguhan tambahan penampilan musikalisasi dari Komunitas Kebun Kata semakin menguatkan tema seminar daring ini sehingga 
tujuan dari seminar daring ini dapat tercapai dengan optimal. Tujuan dari seminar daring ini adalah untuk mempersiapkan masyarakat dalam menghadapi era revolusi industry 4.0 dengan belajar bahasa Inggris sebagai bahasa asing yang banyak digunakan sekarang ini.

\section{Tahap evaluasi (Evaluating)}

Setelah kegiatan seminar ini selesai dilaksanakan, tim kerja bersama dengan Komunitas Duta Bahasa Provinsi Bangka Belitung melakukan evaluasi kegiatan. Evalusi yang dilakukan mencakup proses berjalannya seminar dan hasil seminar yang dilakukan. Evaluasi proses berjalannya seminar dilakukan antara tim kerja dengan panitia dari Komunitas Duta Bahasa Provinsi Bangka Belitung, sementara evaluasi hasil seminar dilakukan dengan melakukan pengujian acak pada beberapa peserta seminar akan pemahaman mereka tentang pentingnya belajar bahasa Inggris dan kemampuan berkomunikasi dalam bahasa Inggris untuk menghadapi era revolusi industri 4.0. Penyusunan laporan menjadi langkah terakhir yang dilakukan dalam tahap evaluasi ini.

\section{HASIL DAN PEMBAHASAN}

Peserta kegiatan seminar ini berjumlah 60 orang dengan latar belakang yang berbeda. Kegiatan seminar ini berlangsung pada puku; 14.00 - 16.30 WIB. Peserta seminar terlihat sangat antuasias dalam mengikuti kegiatan seminar ini. Kegiatan seminar ini terbagi menjadi dua sesi, yaitu sesi penyampaian materi dan sesi diskusi tanya jawab.

Pada sesi penyampaian materi tentang strategi belajar bahasa Inggris, disampaikan tentang strategi belajar bahasa Inggris yang dapat membantu mewujudkan autonomous learning untuk menghadapi era digital 4.0. Seseorang tidak dapat hanya bergantung pada bantuan guru dan sekolah dalam belajar. Seseorang harus lebih memiliki inisiatif pribadi dalam belajar bahasa, begitu juga dengan belajar bahasa Inggris. Seseorang harus lebih memiliki inisiatif pribadi dalam belajar bahasa, begitu juga dalam belajar bahasa Inggris.

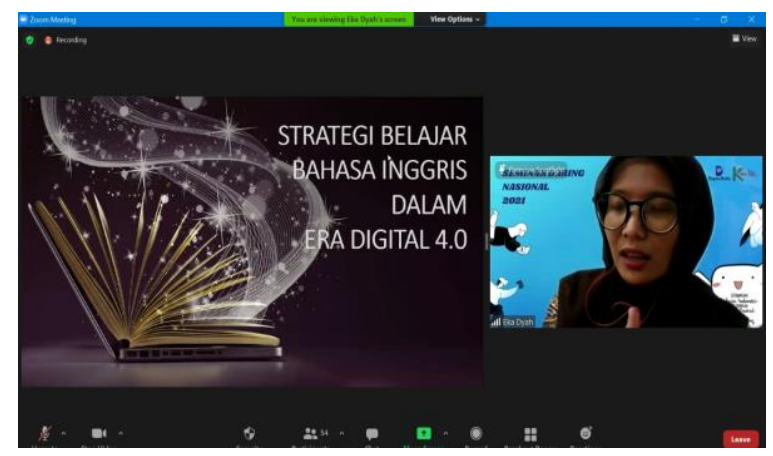

Gambar 4. Pemaparan Materi

Untuk menghadapi era revolusi industri 4.0 ini, empat kemampuan berbahasa Inggris sangat diperlukan, yaitu menyimak, berbicara, membaca, dan menulis. Beberapa cara dapat diambil untuk belajar Bahasa Inggris sendiri dalam era digital 4.0 ini, seperti membaca ekstensif dan mengembangkan kemampuan menulis. Keterampilan membaca dapat membantu seseorang memperoleh informasi dan memahami berbagai konsep dengan mudah. (Novelti et al., 2018) Membaca secara komunikatif digunakan untuk mencari, menemukan, dan memperoleh informasi dari berbagai sumber sesuai dengan pemahaman masing-masing individu yang diperoleh. (Sari \& Rasyid, 2020) Lebih lanjut, membaca dan menulis sangat terkait dan merupakan pintu gerbang untuk mempelajari produktivitas di era digital saat ini. (Mursal \& Ramadhan, 2018) Oleh karena itu, strategi belajar bahasa Inggris di era revolusi digital ini perlu diberikan kepada komunitas yang berfokus pada bahasa dan budaya untuk menyebar luaskan serta meningkatkan keterampilan berbahasa Inggris kepada masyarakat. Kegiatan ini memberikan manfaat yang dapat digunakan secara langsung oleh masyarakat dalam era revolusi digital 4.0 ini. 


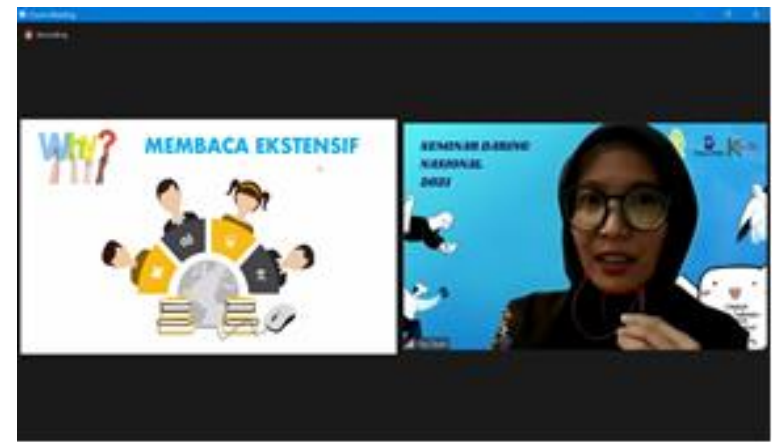

Gambar 5. Materi Membaca Ekstensif

Membaca ekstensif merupakan salah satu pendekatan pembelajaran Bahasa Inggris dengan cara membaca banyak bacaan dalam waktu yang cepat. Pendekatan ini akan meningkatkan kemampuan membaca sekaligus kemampuan bahasa Inggris pada waktu yang bersamaan. Beberapa cara dapat dilakukan dalam membaca ekstensif ini. Salah satu caranya adalah dengan memperbanyak membaca teks bahasa Inggris dalam berbagai genre. Saat seseorang membaca sebuah teks dengan genre yang berbeda, hal ini akan meningkatkan kemampuan berbahasa orang tersebut. Teks yang dapat digunakan untuk membaca ekstensif ini tidak hanya dalam bentuk artikel ilmiah saja. Cerita pendek, novel, buku, dan sejenisnya dapat dijadikan sebagai sumber bacaan yang baik. Dalam era digital 4.0, tidak dapat dipungkiri bahwa beberapa orang mengalami kendala dalam mendapatkan akses buku bacaan. Beberapa kendala yang muncul adalah harga buku yang relatif mahal, stok buku cetak yang terbatas, dan ketiadaan perpustakaan yang cukup menunjang. Gawai dapat menjadi solusi yang menarik seseorang untuk terus membaca. Peran gawai dalam kemampuan membaca dapat menggantikan peran buku atau bacaan.

Membaca buku akan dapat membantu kita memahami banyak hal. Membaca ekstensif merupakan cara yang paling mudah untuk kita lakukan untuk meningkatkan minat membaca. Hal ini dikarenakan membaca ekstensif dapat membantu kita memahami isi buku secara singkat dengan mengetahui garis besarnya, mendapatkan pemahaman yang dangkal dengan mengetahui inti bacaan, mengetahui kesan pembaca, dan menemukan referensi yang tepat. Tujuan membaca ekstensif ini dapat dilakukan dengan berbagai jenis kegiatan membaca. Beberapa jenis membaca ekstensif ini adalah 1) membaca survei, dimana saat membaca kita menemukan hal-hal yang umum tentang teks, seperti halaman judul, kata-kata penulis, ringkasan, bagan, diagram, kesimpulan, dan referensi, 2) membaca sekilas merupakan Teknik membaca cepat dengan mencari titik dalam teks dengan cara membaca paragraf pertama dan terakhir, dan biasanya Teknik ini digunakan untuk membaca artikel di majalah dan koran, dan 3) membaca dangkal, dimana Teknik membaca ini akan menemukan informasi umum dangkal dari teks yang akan dibaca, biasanya Teknik membaca ini digunakan untuk membaca yang bersifat kasual, seperti membaca majalah, novel, dan cerpen.

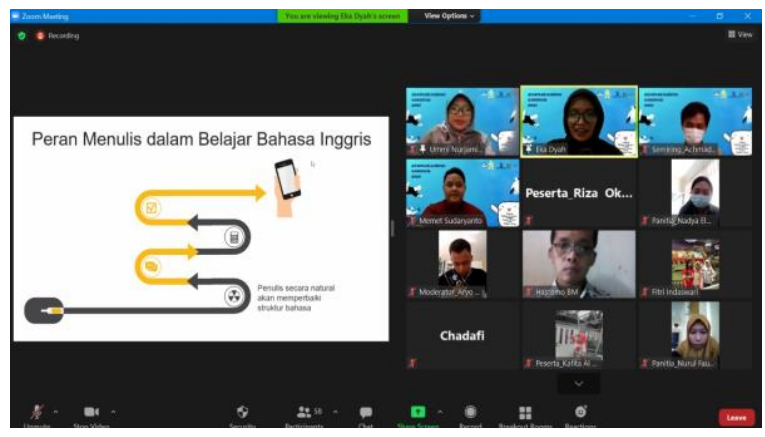

Gambar 6. Materi Menulis

Selain membaca ekstensif, strategi belajar lainnya adalah dengan cara mengembangkan kemampuan menulis. Saat seseorang mampu mengembangkan kemampuan menulisnya, orang tersebut akan mengembangkan kemampuan bahasanya yang lain dengan sendirinya. Saat seseorang akan mengembangkan kemampuan menulis, berbagai media dapat digunakan sebagai alat bantu, seperti blog, media sosial, artikel ilmiah, dan sebagainya. Kemampuan menulis seseorang dapat digunakan untuk menunjukkan 
kualitas dirinya saat dia harus menulis dalam konteks akademik, misalnya menulis esai untuk mendaftar ke kampus idamannya, untuk mendapatkan beasiswa, atau untuk berbagi pengetahuan dengan komunitas.

Selain hal tersebut, kemampuan menulis juga merupakan hal yang penting dalam pembelajaran Bahasa Inggris. Kemampuan menulis akan membantu kita terampil dalam berpikir dan menyampaikan ide, perasaan ataupun gagasan secara logis dan sistematis. Selain itu, menulis juga dapat meningkatkan kemampuan kognitif kita, dimana dengan menulis sebuah topik atau artikel, pemahaman kita akan topik atau artikel tersebut akan lebih mendalam.

Alasan lain yang muncul akan pentingnya kemampuan menulis adalah memperkaya pertumbuhan personal, mengekspresikan diri kita dalam cara yang lebih efektif, dan meningkatkan pemahaman yang lebih mendalam akan diri kita, lingkungan, orang lain, dan hidup. Dengan kata lain, sebuah tulisan yang baik akan menjadi kunci sukses kita dalam bidang akademik dan karir.

Hal yang sama juga berlaku saat kita belajar bahasa Inggris. Tulisan bahasa Inggris yang baik akan menciptakan hubungan yang menguntungkan karena kemampuan menulis sangat berperan penting untuk peningkatan kemampuan bahasa Inggris. Saat seseorang belajar menulis dalam bahasa Inggris, orang tersebut juga secara tidak langsung akan menyampaikan gagasan, ide, dan pemikirannya dalam bahasa tulis yang efektif agar makna dan pesan yang terkandung dapat tersampaikan dengan baik kepada pembaca. Oleh sebab itu, keterampilan seseorang dalam mengolah kalimat dalam Bahasa Inggris akan semakin terasah.

Terdapat beberapa alasan kenapa menulis berperan penting dalam pembelajaran bahasa Inggris. Pertama, seorang penulis akan secara natural memperbaiki struktur bahasanya. Hal ini berkaitan dengan tata bahasa, penguasaan kosa kata, dan kala (tense) dalam bahasa
Inggris. Kedua, menulis akan meningkatkan kemampuan berkomunikasi dengan orang lain dalam cara yang lebih efektif. Ketiga, menulis akan meningkatkan fokus, pengetahuan, kreatifitas, dan imajinasi. Saat pengetahuan dan kreatifitas seseorang meningkat, akan menjadi lebih mudah bagi orang tersebut untuk menjadi sukses dalam bidang pribadi, akademik, dan karir. Peningkatan dalam bidang akademik dan karir akan secara otomatis meningkatkan kepercayaan diri seseorang dalam berkomunikasi dan berinteraksi dengan orang lain.

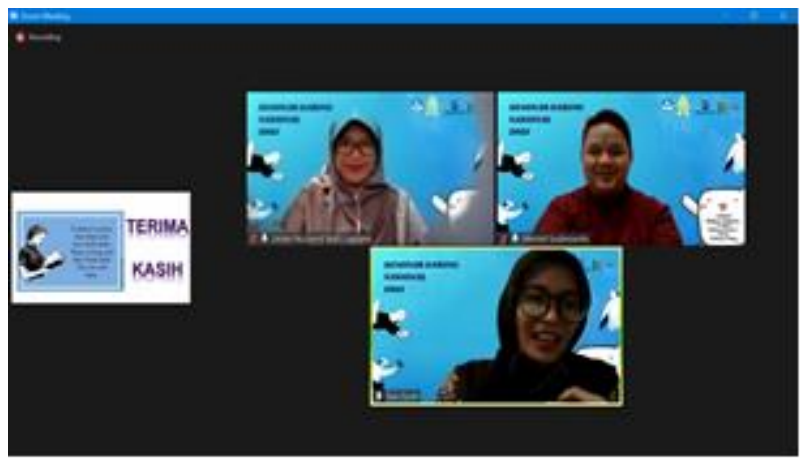

Gambar 7. Pemaparan Materi Akhir

Pada sesi diskusi dan tanyajawab, para peserta menunjukkan tingkat antusiasme yang tinggi. Peserta bertanya tentang implementasi sederhana dalam belajar bahasa Inggris dan cara mengaplikasikan strategi belajar tersebut dalam kehidupan sehari-hari. Melihat antusiasme peserta akan topik yang disajikan menunjukkan bahwa materi yang disajikan memenuhi harapan mereka akan kegiatan seminar ini dan meningkatkan minat mereka dalam belajar bahasa Inggris. Hasil ini sesuai dengan target dari kegiatan, yaitu untuk menumbuhkan minat dan motivasi belajar bahasa Inggris untuk membantu menghadapi era digital 4.0. Akan tetapi, tetap dibutuhkan ketekunan lebih lanjut dari peserta secara mandiri untuk dapat mencapai hasil belajar bahasa Inggris dengan optimal. 


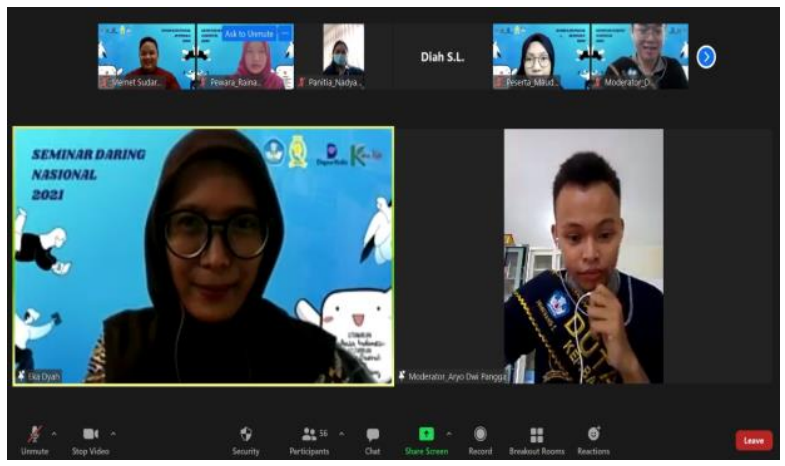

Gambar 8. Sesi Diskusi dan Tanya Jawab

\section{KESIMPULAN}

Di era digital 4.0 ini, seseorang tidak dapat hanya bergantung pada bantuan guru dan sekolah dalam belajar Bahasa. Beberapa cara untuk belajar Bahasa Inggris di era digital 4.0 ini adalah dengan membaca ekstensif (extensive reading) dan mengembangkan kemampuan menulis. Membaca ekstensif merupakan pendekatan pembelajaran Bahasa Inggris dengan cara membaca banyak bacaan dalam waktu yang cepat. Terdapat tiga jenis membaca ekstensif yaitu membaca survei, membaca sekilas, dan membaca dangkal. Cara yang kedua adalah mengembangkan kemampuan menulis. Tujuan dari mengembangkan menulis dalam pembelajaran Bahasa Inggris adalah untuk menunjukkan kualitas diri saat menulis esai untuk mendaftar beasiswa atau untuk berbagi pengetahuan. Salah satu peran menulis dalam pembelajaran Bahasa Inggris adalah peningkatan dalam akademik dan karir. Saat seseorang sudah mengalami peningkatan dalam akademik dan karir, secara otomatis orang tersebut juga meningkatkan kepercayaan dirinya dalam berkomunikasi dan berinteraksi dengan orang lain dalam Bahasa Inggris. Peserta yang mengikuti kegiatan ini menunjukkan tingkat antusiasme yang tinggi tentang implementasi sederhana dalam belajar bahasa Inggris dan cara mengaplikasikan strategi belajar tersebut dalam kehidupan sehari-hari. Hal ini memenuhi harapan mereka akan tujuan kegiatan ini yaitu untuk menumbuhkan minat dan motivasi belajar bahasa Inggris untuk membantu menghadapi era digital 4.0.

\section{DAFTAR PUSTAKA}

Firmansyah, D. B., Mahmudah, S., \& Utami, B. (2021). Pelatihan English Speaking Skill Untuk Siswa-Siswi MTS N 8 Kebumen: Merawat Kreativitas Selama Pandemi Covid. 1(2), 119-131.

Lestari, Y., \& Erwanto, E. (2021). Literasi Digital di Era Revolusi Industri 4.0. Jurnal Pengabdian Kepada Masyarakat (Abdimas) Universitas Baturaja, 2(1), 71-77.

Muliyah, P., \& Fernando, F. (2019). Pelatihan pengenalan Bahasa Inggris untuk Anak Usia Dini melalui Igra. DEDIKASI: Jurnal Pengabdian Masyarakat, 1(1), 20-36.

Mursal, M., \& Ramadhan, S. (2018). Development of Writing Learning Model Using Process Approach In Class III Elementary School. January 2018. https://doi.org/10.2991/iclle-18.2018.16

Novelti, N., Ramadhan, S., Ermanto, E., \& Agustina, A. (2018). Developing an Instructional Model Assisted Audio Visual Media. 263(Iclle), 111-116. https://doi.org/10.2991/iclle-18.2018.17

Noviana, F., Trahutami, S., Hesti, E. I., \& Rosliana, L. (2018). Jurnal "HARMONI" , Volume 2 Nomor 2, Desember 2018 Departemen Linguistik FIB UNDIP. Harmoni, 2, 41-46.

Permata, N. N., \& Hadiani, D. (2018). Pelatihan Bahasa Inggris Dasar Dalam Upaya Peningkatan Kemampuan Mahasiswa Mahasiswa Bidikmisi Polman Bandung. Paper Knowledge . Toward a Media History of Documents, 2(4), 1-5.

Purwati, Y., \& Perdanawanti, L. (2019). Pelatihan Desain Menggunakan Aplikasi Canva Untuk Anggota Komunitas Ibu Profesional Banyumas Raya. 1(1).

Sari, Y., \& Rasyid, Y. (2020). Hubungan Antara Keterampilan Membaca Pemahaman Dengan Keterampilan Menulis Teks Laporan Hasil Observasi Siswa Kelas X Smk Negeri 3 Padang. Jurnal Ilmiah Pendidikan Bahasa Dan Sastra Indonesia, 1(2), 446-453.

Tamrin, A. F., \& Yanti, Y. (2019). 
Peningkatan keterampilan bahasa Inggris masyarakat pegunungan di Desa Betao Kabupaten Sidrap. Transformasi: Jurnal Pengabdian Masyarakat, 15(2), 61-72. https://doi.org/10.20414/transformasi.v15 i 2.1673

Thariq, P. A., Husna, A., Aulia, E., Djusfi, A. R., Lestari, R., Fahrimal, Y., \& Jhoanda, R. (2021). Sosialisasi Pentingnya Menguasai Bahasa Inggris Bagi Mahasiswa. Jurnal Pengabdian Masyarakat: Darma Bakti Teuku Umar, 2(2),

316. https://doi.org/10.35308/baktiku.v2i2.283 5 